\title{
Chapter 13 \\ Urban Metabolism Evaluation Methods: \\ Life Cycle Assessment and Territorial \\ Regeneration
}

\author{
Pasquale De Toro (D) and Silvia Iodice
}

\subsection{Introduction: The City as an Urban Ecosystem and the Concept of Life Cycle}

The co-evolution of human and natural systems results in the interpretation of cities as hybrid ecosystems, that are unstable and unpredictable, but also capable of innovating (Alberti, 2015). A city, if treated as an ecosystem, can be better evaluated (Collins et al., 2000). In the present work, a shift is proposed from the 'ecology in cities' approach to the 'ecology of cities' approach. The first approach links ecological approaches in urban areas (Grimm et al., 2008; Sukopp, 2008), whereas the second incorporates the first approach and expands it by considering the city itself as an ecosystem (McPhearson et al., 2016).

What primarily characterises ecosystems is the search for consistency and coordination between the components. From this perspective, cities are ecosystems, living organisms that are defined by a high level of complexity and in continuous transformation, produced by the union of cultural and natural events, and that are composed of places endowed with identity, history, character and long-term structures (Magnaghi, 2010). Another main feature of urban ecosystems is the presence of dynamic boundaries and a high dependence on their fringe environments. Three main components of urban ecosystems have been identified (Chen et al., 2014):

- Structures, which are based on the distribution of organisms, including humans, as well as landscape patches, and soil, atmospheric and hydrologic patterns;

\author{
P. De Toro $(\bowtie)$ \\ Department of Architecture (DiARC, UNINA), University of \\ Naples Federico II, Naples, Italy \\ e-mail: pasquale.detoro@unina.it \\ S. Iodice \\ European Commission, Joint Research Centre (EC, JRC), Ispra, Italy \\ e-mail: silvia.iodice@ec.europa.eu
}


- Processes, which are based on various forms of communications as well as political and cultural activities, together with economic and ecological processes in the built environment;

- Functions, such as resource consumptions and ecosystem services.

Urban ecosystems are defined as: 'dynamic, three-dimensional combinations of natural, social and built features, and their functions, associated with an urban area' (Brown, 2017, p. 10). They are mostly influenced by human actions, but are not totally dependent on them (Hobbs et al., 2006), and they are the result of human and ecological processes occurring simultaneously in time and space (Alberti, 2008).

Urban ecosystems face many difficulties because of rapid and major urbanisation phenomena, leading to dramatic environmental changes at different scales, from local to global (Buhaug \& Urdal, 2013; Pataki et al., 2006). Moreover, because they are a concentration of people and human activities, urban ecosystems are also energyintensive, determining their being more unbalanced than many other ecosystems, and characterised by a heterotrophic nature, because of their strong dependence on external energy sources (Collins et al., 2000).

Urban ecosystems are also part of the wider territory: they are complex and open systems that interact with other territories, such as the ecosphere and biosphere, and that are transformed, used and managed by a system of actors who relate to each other in socially organised forms. Loiseau et al. (2018) propose identifying three main dimensions of a territory: a material dimension defined by its physical components, an organisational dimension defined by the presence of social and institutional actors, and an identity dimension defined by the way social and institutional stakeholders interact with the territorial system.

Another important distinction must be made between urban and peri-urban areas; the latter are portions of territory in transition, that are characterised by a juxtaposition of activities and by the possibility of alterations and modifications of their features due to human activities (Douglas, 2012). These complex systems are crossed by economic, ecological and social flows whose quality and quantity is strongly influenced by human activities (Rotmans et al., 2000).

Urban ecosystems are characterised by the interaction of environmental, economic and social dynamics and they are areas in which a high rate of production of negative externalities is concentrated. From this perspective, cities are less balanced than human-free ecosystems and 'the feedback control of ecological consequences to social policy is relatively weak' (Collins et al., 2000, p. 140).

As ecosystems, cities have to face many challenges, such as population growth, pollution, changes in climate and water systems and soil consumption (McPhearson et al., 2016). Consequently, the amount of built infrastructures is increasing (Ahern et al., 2014), with negative consequences for natural resources at different scales. Urban ecosystems have not yet been appropriately incorporated into the various forms of urban governance and planning approaches aimed at increasing resilience, despite the strong need for such integration (McPhearson et al., 2016).

These ecosystems are also crossed by metabolic processes that define the interconnections of different life cycles (Russo, 2017, 2018). The concept of the life 
cycle of urban ecosystems is related to the evolution of the territory as a heritage and as a system of environmental, social and economic resources and services, whose transformation is linked to the governance of that particular territory. The territorial life cycle is formed in subsequent phases that are influenced by the systems of resources and performances of that territory, which follow a predefined plan scenario (Torricelli, 2015a).

According to Zucchetti (2008), in a systemic conception, a certain portion of the territory does not have the possibility of growing indefinitely. It can undergo an involution phase, that manifests itself with an increasing degree of entropy and a reduction of the value of the ecosystem. This process will continue until the creation of a new system with a different structure and a new life cycle is started.

In general, there are many different drivers that can determine the evolution of the territorial life cycle-not only economic factors, but also social and environmental ones-and each case has its own specificity.

Carta (2013) identifies three categories of life cycles:

- Completed or never born life cycles: These are spaces of abandonment and waste, closed workspaces, and unfinished or no-longer-used structures. In these areas, it is possible to adopt an up-cycle process and activate transformations capable of giving life to multiple functions, with a view to hyper-cycling;

- Seasonal life cycles: These are linked to the system of second homes and tourism in crisis because they are on sale or subject to a real estate crisis. Additionally, in this case, the hyper cycle, acting on the causes of territorial decline, allows the activation of new life cycles and thus promotes the regeneration of new connection networks;

- Productive life cycles in 'border landscapes': These are production areas that generate wasted landscapes, requiring a linear production cycle's transformation into a circular production cycle. Here, it is possible to apply the concept of subcycles and the 'from cradle to cradle' approach, creating new, resilient and adaptive processes.

The speed that distinguishes the succession of different life cycles and the consequent consumption of resources determines the unavoidable formation of residual spaces, or wastescapes (Amenta \& Attademo, 2016). At the end of their life cycle, wastescapes await the start of regeneration actions.

If the city is like a living organism, the start of a new life cycle in a wastescapethrough proliferation and hybridisation of the surrounding tissues-can transform a group of undifferentiated cells, giving rise to new organs. Areas subject to recycling actions are like sprouts that generate new connective tissues (Carta, 2013). The concept of a life cycle can be compared to that of change and it is also closely linked to the analogy of ecosystems and the urban environment, which forms the basis of the idea of a city as an organism in constant transformation (McDonough \& Braungart, 2002). In this sense, cities, in their making and unmaking, are seen as renewable resources. Recycling the city is a fundamental strategy that touches upon scales and themes of contemporary urban challenges (Ciavatta, 2016). 
This recycling action, from the perspective of the circular economy, strongly needs the help of decision-making tools and quantification methodologies that are based on the environmental impact assessment principles.

\subsection{Environmental Assessment: Agendas, Methods and Tools}

The general concept of environmental assessment was introduced in the 1970s, with the aim of integrating the environmental component into decision-making processes as well as analysing the state of the environment and increasing citizens' awareness of environmental issues (Lerond et al., 2003).

There are no standardised methodologies for territorial environmental assessment, despite the existence of a wide number of tools and methods with this purpose (Loiseau et al., 2012).

From this perspective, environmental assessment is an instrument of considerable importance because the high concentration of people in urban ecosystems puts massive environmental pressure on not only ecosystems and natural resources, but also on the well-being and quality of life of the ecosystem's inhabitants. As soon as the concept of sustainable development was introduced (Brundtland, 1987), a variety of methods for environmental assessment was proposed and developed to enhance territorial sustainability. Environmental assessment can be defined as an instrument that aims to support land planning and management decision-making processes and provide environmental information using a global approach (Torricelli \& Gargari, 2015a).

Ness et al. (2007) subdivide these methods into three categories:

- Methods based on the use of indices and indicators. Whereas an indicator, using observed or estimated data, describes one characteristic of the state of the environment (Dizdaroglu, 2015), while an index represents a quantitative aggregation of many indicators, thus providing a simplified view on the state of the environment (Mayer, 2008). Many indices of sustainability on an urban scale have been developed by different organisations and from different perspectives (Albertí et al., 2017). For example, consider the City Sustainability Index (Mori \& Christodoulou, 2012) and the Environmental Performance Index (EPI) (Esty et al., 2005);

- Integrated assessment methods, which are used to investigate policy changes or project implementation statuses using development scenarios. In this category, some examples are Multi-Criteria Decision Analysis (MCDA), Cost-Benefit Analysis (CBA) and impact assessment (such as the Environmental Impact Assessment [EIA] and the Strategic Environmental Assessment [SEA]) (Dizdaroglu, 2015);

- Methods that assess sustainability on the scale of a single product and that focus on the material and energy flows of a product or service by adopting a life cycle 
perspective (Dizdaroglu, 2015). Noteworthy examples are the Ecological Footprint (EF) (Wackernage \& Rees, 1997), which is sometimes based on the concept of 'carrying capacity' (Rees, 2017), Material Flow Analysis (MFA), Substance Flow Analysis (SFA), Physical Input-Output Tables (PIOT), Ecological Network Analysis (ENA), Emergy, Exergy and Life Cycle Assessment (LCA).

Dizdaroglu (2015) proposes that the so-called 'indicator-based sustainability assessment' be added to this list. This assessment uses urban ecosystem indicators in order to achieve urban sustainability. Moreover, Albertí et al. (2017) propose a detailed description and classification of some sustainability indices developed for cities.

Urban ecosystems are increasingly becoming a part of the various agendas for sustainable development (Albertí et al., 2017); these agendas aim to improve their economic growth management and avoid social instability and environmental degradation (Rotmans et al., 2000). For example, the 2030 Agenda for Sustainable Development ${ }^{1}$ was developed to integrate the Millennium Development Goals and balance the three dimensions of sustainable development. The Agenda consists of $17 \mathrm{objec}-$ tives, known as Sustainable Development Goals (SDGs), and 169 targets. One of the most significant goals in relation to urban ecosystems is Goal no.11: to make cities and human settlements inclusive, safe, resilient and sustainable.

Another important example is the New Urban Agenda, adopted during the United Nations Conference on Housing and Sustainable Urban Development (Habitat III), ${ }^{2}$ which promotes urban development that is respectful of the environment and that provides guidance for the achievement of SDGs.

In light of this overview, the aim of this chapter is to bring greater clarity to the environmental assessment methods-particularly those related to Urban Metabolism (UM), which is introduced in the next sub-chapter. A specific area of focus is the LCA method, which, in recent years, has shown promise in relation to its possible use on a territorial scale, to support the decision-making phase linked to urban governance and territorial regeneration processes.

\subsection{Cities of Flows: The Concept of UM and Its Evaluation Methods}

Comparing urban ecosystems to organisms crossed by metabolic flows shows the necessity of introducing in this sub-chapter the concept of UM. Metabolism in general refers to the biochemical reactions of synthesis and degradation that occur in every living organism in order to sustain its growth, renewal and maintenance.

$\mathrm{UM}$ is a scientific phenomenon comprising individual processes that take place in all cities at different spatial and temporal scales (Kennedy et al., 2014) and that are based on the principle of conserving mass and energy. Urban ecosystems are powered

\footnotetext{
${ }^{1}$ http://www.2030agenda.undp.org/content/2030agenda/en/home.html.

${ }^{2} \mathrm{http}: / /$ habitat3.org/the-new-urban-agenda/.
} 
by incoming flows that allow the processes of the use and consumption of resources to be carried out, generating outgoing flows in the form of waste and emissions. The territory as an organism is characterised by a sequence of vital phases, which, while influencing its metabolism, also have an impact on the functioning and the shape of the territory and of its networks (Russo, 2015).

Analysing the metabolism of a city makes it possible to understand the impacts of urban development (Mostafavi et al., 2014), taking into account the flows of energy, water, nutrients and waste, and of the materials in general that circulate within a city, and allowing a multidimensional assessment of sustainability (Beloin-SaintPierre et al., 2017). This phenomenon can be analysed according to four fundamental flows: water, materials, energy and nutrients (in the input and output of the system). It is currently mainly characterised by a linear development model. The metabolic functioning of an urban area affects not only its flows but also the anthropogenic stocks that transform the input flows into the so-called 'grey infrastructure', which shapes the physical environment of urban areas and determines their development models.

$\mathrm{UM}$ is not an isolated phenomenon, but it is strictly connected to the functioning of urban areas. Minx et al. (2011) underline the necessity of associating metabolic flows with some characteristic aspects of cities, such as land use-intensity, urban form and size and population density, as well as other kinds of phenomena, such as land use planning and citizens' lifestyles, described as urban drivers, urban patterns and urban lifestyles (Fig 13.1).

In general, given the growing interest in environmental issues, UM has become a key concept in quantifying the level of urban sustainability and consumption of resources (Qi et al., 2017), as well as in assessing environmental impacts and opening the way to innovative systemic approaches. The same flows that pass through cities and that can lead to an exhaustion of their life cycles if carefully quantified, can instead represent the potential to guarantee a sustainable urban life.

In general, many approaches and applications are used to compare, from a quantitative point of view, the environmental sustainability of different scenarios of urban consumption/production (Beloin-Saint-Pierre et al., 2017). Furthermore, as Li and Kwan (2018) state, UM can be examined at different spatial scales: global UM studies analyse the global anthroposphere, whereas other studies analyse the national or regional scale as well as the urban and local dimensions. UM determines the necessity to adopt a flow perspective of urban ecosystems (Dijst et al., 2018).

Many authors have explored the phenomenon of UM and experimented with indices and evaluation methods, but there is still no consensus on the assessment methods to use; there are, indeed, many different experimental approaches.

For example, Kennedy et al. (2014) propose a complex indicator to evaluate the UM of some large cities (megacities), with the aim of collecting information related to multiple aspects, such as the biophysical characteristics of the climate and population, the metabolic flows of water, waste, materials and energy linked to spatial boundaries and constituent urban elements. 


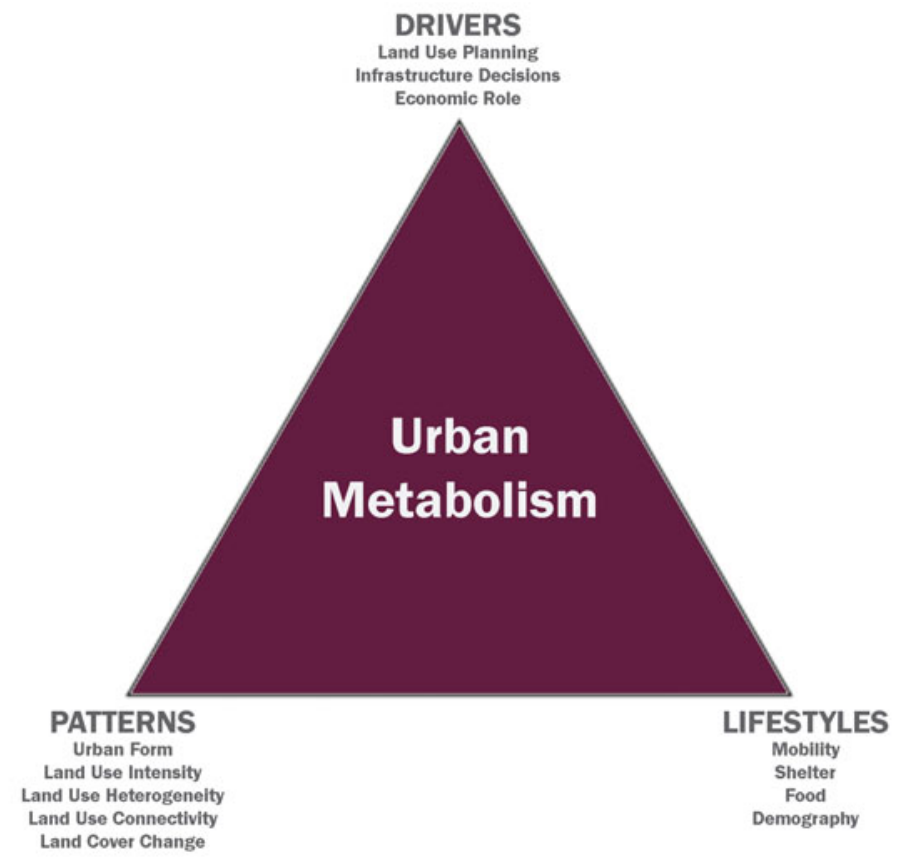

Fig. 13.1 UM drivers, patterns and lifestyles (Adapted from Minx et al., 2010)

In their study, Kennedy et al. (2015) subsequently demonstrate that megacities are responsible for consuming $9 \%$ of the world's electricity, generating $13 \%$ of its solid waste and housing $7 \%$ of its global population.

Conke and Ferreira (2015) evaluate the changes in matter and energy that took place in a city in Brazil in the period between 2000 and 2010, aiming to monitor urban transformations and the contribution of cities to sustainable development. Further, Mostafavi et al. (2014) propose an integrated analysis framework called Integrated Urban Metabolism Analysis Tool (IUMAT), based on the quantification and aggregation of human, social and environmental capital linked to urban activity. Giampietro et al. (2009) propose the Multi-Scale Integrated Analysis of Societal and Ecosystem Metabolism (MuSIASEM) approach, which is based on the analysis of the patterns of metabolism of socio-economic systems at different levels and scalesespecially those linked to socio-economic activities and ecological constraints.

Despite the development of many evaluation tools, there is still a lack of consensus on the most suitable evaluation methods and techniques for evaluating UM.

At the European level, the important approaches and research projects are as follows:

- The REPAiR project ${ }^{3}$ (REsource Management in Peri-Urban AReas: Going Beyond Urban Metabolism), which investigates the link between UM, waste

\footnotetext{
${ }^{3}$ http://h2020repair.eu/.
} 
management and wasted landscapes. UM is deeply examined with reference to some specific waste flows (Organic Waste and Construction and Demolition Waste), and their spatial implications verified through the MFA and LCA.

- SUME project ${ }^{4}$ (Sustainable Urban Metabolism for Europe), which links the evaluation of UM to the spatial component and, in particular, to urban planning. The project assesses development scenarios for six different cities (Athens, Oporto, Monaco, Newcastle, Stockholm and Vienna) up to 2050 in relation to three layers: soil consumption, energy consumption and materials consumption. UM is investigated according to the main flows crossing these territories, with special emphasis on the flows' impact on the urban form.

- UrbanWINS ${ }^{5}$ (Urban Metabolism Accounts for Building Waste Management Innovative Networks and Strategies), in which UM is again focused on waste flows with the aim of identifying innovative and sustainable strategic plans for waste prevention and management.

- UrBAN-WASTE ${ }^{6}$ (Urban Strategies for Waste Management in Tourist Cities), which is aimed at developing strategies able to reduce the amount of municipal waste production and to reintroduce waste as a resource into UM flows.

- BRIDGE project ${ }^{7}$ (Sustainable Urban Planning Decision Support Accounting), which uses a bottom-up approach to quantitatively assess UM on the local scale, connecting biophysical sciences to urban planning. ${ }^{8}$ In this case, the metabolic flows represented by energy, water, carbon and pollutants are quantitatively assessed on the local scale.

According to Beloin-Saint-Pierre et al. (2017), who review the main UM studies, more than 150 of those studies use different UM assessment methodologies and analyse more than 60 cities.

The authors propose three main typologies of system modelling:

- The Black-Box (BB) approach, which is based on the description of flows in the input and output of the system;

- The Grey-Box (GB) approach, which disaggregates the flows in the input and output according to the different components (e.g. buildings, roads);

- The Network (NE) approach, which is similar to the GB approach, but also describes the environmental impacts of specific components of the assessed life cycle.

Furthermore, Li and Kwan (2017) state that UM assessment methods can be divided into two main categories: 'material-based analysis', which includes MFA, LCA, Ecological Footprint Analysis (EFA), SFA, Input-Output Tables (IOTs), and ENA and

\footnotetext{
${ }^{4}$ https://www.sume.at/.

5 https://www.urbanwins.eu/.

${ }^{6}$ http://www.urban-waste.eu/.

${ }^{7}$ http://www.bridge-fp7.eu/.

${ }^{8}$ Other initiatives can be found at: https://metabolismofcities.org/; https://www.thenatureofc ities.com/2018/07/24/urban-metabolism-real-world-model-visualizing-co-creating-healthy-cit ies/; http://www.urban-waste.eu/urban-metabolism/; https://www.metabolic.nl/.
} 
'energy-based analysis', which studies the energy flows within an urban ecosystem and involves the development of various emergy index systems.

MFA can be used to establish the material and energy balances of a system, whereas the EFA can be used to determine the theoretical area used by people to consume bio-resources and to assimilate waste (Loiseau et al., 2012). MFA distinguishes between 'stocks', which refer to materials accumulating in the system, and 'flows', which refer to elements going in and out of the system (Dijst et al., 2018). Flows and stocks are influenced by the activities that are happening inside the urban ecosystem and that depend on the needs of individuals and communities (Dijst, 2013). Flows can be material (such as energy, water, materials, etc.) or immaterial (such as social capital, culture, etc.) (Dijst et al., 2018). Chen et al. (2014) further subdivide flows into two types: flows of small volume with a high environmental impact (e.g. heavy metals); and flows of large volume with a low environmental impact (e.g. water).

Chen et al. (2014) also present many references of applications of MFA in global cities. In these applications, MFA is used to model the metabolic intensity in relation to urbanisation processes (Douglas, 2012; Hendriks et al., 2000). Meanwhile, SFA instead is used to evaluate the flows of substance in a given area over a given time. IOTs are more focused on monetary flows, whereas PIOT is more focused on physical flows. ENA focuses on system modelling, linking material flows to the ecosystem structure. Last, exergy analysis identifies 'technical improvements or protection measures which should be implemented in order to improve energy performance and to maintain resource availability' (Loiseau et al., 2012, p. 218); emergy analysis provides information on territorial functioning using four indicators that 'reveal the degree of independence of anthropised territories in terms of resource use and of their interaction with their surrounding environments' (Loiseau et al., 2012, p. 218).

Other typologies of UM assessment methods and indicators are: urban ecology models (Chen et al., 2014; Zhang et al., 2006), ecosystem services and land use models (Haase et al., 2014; Kroll et al., 2012), urban transport and accessibility models (Wegener, 2011), and finally urban energy models (Keirstead et al., 2012).

Environmental analysis of UM can also be carried out using another kind of modelling approach: the 'life cycle perspective', which takes into consideration the entire supply chain, from the raw materials extraction to the waste treatment (Beloin-Saint-Pierre et al., 2017). Indeed, some authors (Beloin-Saint-Pierre et al., 2017; Loiseau et al., 2013) suggest adopting a life cycle and multi-criteria approach, highlighting at the same time the difficulties in the practical application of this methodology at the territorial level because of the absence of a standardised methodology.

An important study in this regard is Goldstein et al. (2013), which proposes a hybrid approach based on the integration between UM and LCA (UM-LCA) to quantify environmental impacts by modelling both upstream (i.e. incoming) flows, and downstream, (i.e. outgoing) flows, and introducing a set of appropriate indicators.

Definitely, there is a clear need to evaluate the environmental loads connected to the upstream and downstream processes related to the metabolic flows of a city and to 
select the best approach in order to guarantee an efficient environmental assessment. The LCA approach has proven to be a very promising tool to support territorial regeneration actions and in the next section a small in-depth analysis is presented.

\subsection{LCA and Territorial Regeneration: Is There any Correlation?}

The present section focuses on the LCA method, which is used to evaluate the environmental impacts related to the life cycles of single products and services. The first examples of LCA applications appeared around the 1970s, in conjunction with the evolution of the concept of sustainable development and with the increase in the amount of attention being paid to identifying strategies aimed at reducing environmental impacts.

LCA is an objective procedure for evaluating energy and environmental loads related to a process or activity. It is performed by identifying the energy and materials used and the waste products and emissions released into the environment. The assessment includes the whole life cycle of the process or activity, from the extraction and processing of raw materials to transportation, manufacturing, distribution, use, reuse, recycling and final disposal (Society of Environmental Toxicology \& Chemistry, 1993).

During an LCA application, impact indicators are divided into two categories: midpoint, expressed in the form of impact categories and subject to a characterisation process and endpoint, representing damage categories obtained by submitting midpoint indicators to normalisation (Fig. 13.2). This kind of analysis, which has to take into consideration the entire life cycle of a product or service, starts from the production of raw materials to their disposal; from the life cycle thinking perspective, these macro phases are referred to as 'from cradle to grave'.

Over the years, there has been an increase of LCA application, with the introduction of variations of scale and therefore a distinction between LCA at the single product level and LCA at the meso (e.g. municipal) and macro levels (European Commission et al., 2010). The LCA approach could prove to be a valid tool for assessing the sustainability of a territory by adopting appropriate methodological modifications and hybridisations (Torricelli \& Gargari, 2015b). The LCA approach is evolving from the single product scale; applications and hypotheses at scales that are different from the micro one are becoming well recognised (Hellweg \& Milà i Canals, 2014; Saner et al., 2013), such as those supporting decision-making in land management.

Loiseau et al. (2012) propose an approach called 'Territorial LCA', which establishes a comparison between different methods for implementing the European Directive (2001/42/EC) on SEA. After the lack of success of MFA and ENA, it is demonstrated that the LCA approach can provide a complete framework for the assessment of territorial sustainability. The framework the authors propose starts from the 'goal 


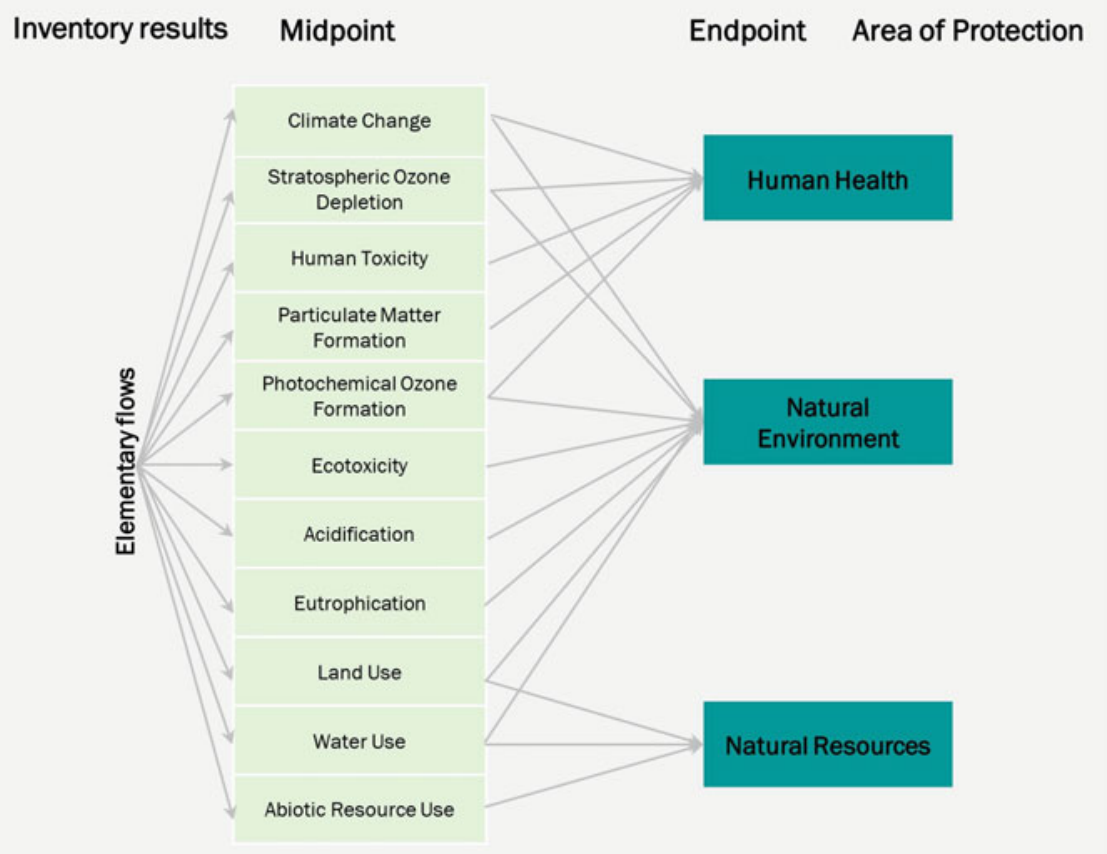

Fig. 13.2 Impact categories (Adapted from Hauschild \& Huijbregts, 2015)

and scope definition', that from a territorial point of view is formed by the studied territory, compared to a system of flows defined by a set of Land Use Functions (LUF), representing the goods and services that the use of land is able to provide. Subsequently, the method is based on the 'activity inventory', which comprises all the consumption and production activities of the given territory. The last phase is the 'indicator evaluation' for the assessment of the territorial environmental impacts (Loiseau et al., 2014).

Through this approach the usefulness of the LCA method is demonstrated for evaluating the sustainability of a territorial system. The applicability of the 'Territorial LCA' is tested through experimentation in a French Mediterranean case study (Loiseau et al., 2014).

The starting point of this approach is indicated by the presence of a geographical area associated with a territorial planning scenario. The objective is to evaluate the eco-efficiency of this area, identifiable as a system of flows. The inventory phase considers all the production and consumption activities, including upstream processes linked to these activities in a defined temporal scenario. The outputs are a vector of environmental impacts and a vector of LUF.

Production activities include agriculture, aquaculture, fisheries, quarrying, manufacturing, shops and services, and consumption activities are those performed by 
inhabitants and tourists. Societal, economic and environmental LUF are considered and are assessed through performance indicators. Precise data about the activities are collected, including the types and amounts of goods and services consumed or produced. The results show that the human health and ecosystem quality impact categories witness a higher impact from production activities than from consumption activities. A distinction is made between in-site impacts, which are caused by environmental flows that occur in the territory and off-site impacts, which are caused by environmental flows happening outside the territorial border. A baseline scenario is developed for future comparisons and for supporting SEA.

Later on, Loiseau et al. (2018) propose a further clarification, dividing territorial LCA into two main approaches (p. 474):

- 'Type A, which focuses on the assessment of a specific activity or supply chain anchored in a given territory';

- 'Type B, which attempt to assess all production and consumption activities located in a territory, including all environmental pressures embodied in trade flows with other territories'.

Another important approach linked to the application of LCA to a territory is the 'Regionalised LCA' approach. It involves the use of regionalised impact assessment methods to compare the environmental impacts between different locations of resource extraction or emission through the Geographic Information System (GIS) support (Hellweg \& Milà i Canals, 2014). Nitschelm et al. (2016) underline the necessity of expanding the potentiality of territorial LCA by using spatially explicit data and by considering the territorial nature of urban planning decisions, as well as taking into account the locations of activities in a spatially explicit manner. Therefore, they propose a spatialised LCA (STLCA) with reference to agricultural territories, which considers the locations of the emissions and uses spatially explicit databases and GIS to geolocalise the various territorial processes. Gargari (2015) conducts an environmental impact assessment based on the life cycle methodology of the LUF 'river boat service' in a protected natural area. Finally, as already previously specified, many authors propose to integrate LCA and SEA to develop a life cycle and multi-criteria approach in the field of urban planning (Beloin-Saint-Pierre et al., 2017; Bidstrup et al., 2015; Björklund, 2012; Loiseau et al., 2012, 2013).

In conclusion, there are many significant emerging approaches that aim to identify environmental hotspots and to support decision-making for the improvement of future policies' environmental performances (Loiseau et al., 2018).

\subsection{Conclusions}

Urban ecosystems are complex and, like living organisms, have their own metabolism. This metabolism's functioning is linked to the presence of input and output streams. The territory is commonly considered a geographical space managed by local stakeholders and characterised by a regional identity. The inclusion of this 
concept in the application of LCA is still being debated (Mazzi et al., 2017). New definitions and experimental applications are required to facilitate this inclusion. The use of spatially explicit data is necessary to evaluate the environmental impacts of a territory. Although LCA was born as an approach that was independent of spatial characteristics, it is necessary to remember that environmental and administrative decisions take place in a territory. The activities' locations should be examined in a spatially explicit way, starting from the assumption that emissions and impacts take place in different locations (Nitschelm et al., 2016).

Urban ecosystems are endowed with a high potential to reduce the input and output flows of resources through a more efficient territorial management. Such management is based on a better spatial organisation and implements circular practices in all the life cycle phases, in order to reduce resource consumption.

To achieve an urban management style that can be defined as resource-efficient, it is advisable to have a detailed knowledge of the territory and the urban metabolic flows (European Environment Agency, 2015). This would make it possible to guide decision-makers in defining sustainable planning choices. Further, to stem the negative externalities, it is also necessary to create a territorial government system that prioritises a sustainable environmental protection and considers the territory as a complex dynamic system.

The need to protect the environment and its resources, as well as achieve the sustainable valorisation of urban and peri-urban spaces, is an unavoidable reality (Scarmellini, 2015). Urban and peri-urban areas are sources of environmental pressures that go even beyond their own territorial borders. This makes clear the need to quantify the metabolic flows going in and out of urban ecosystems through appropriate methodologies that include the territorial component. In conclusion, it is only when we start with a detailed cognitive overview of the urban environment and of its most important matrices, is it possible to offer support to the decision-makers involved in the territorial regeneration. One of the prerogatives to go in this direction is that it allows one to evaluate urban metabolic flows and their spatial implications in order to support urban governance. One needs to select appropriate methods to support this form of governance, such as LCA, which has already shown that it can offer a detailed metabolic characterisation of a territory.

Authors' Contributions The present work has been developed through a strict collaboration between the authors. In particular Pasquale De Toro wrote the second chapter, providing as well a general overview of the entire structure, while Silvia Iodice wrote all the other chapters. Both the authors contributed to the conclusions. 


\section{References}

Ahern, J., Cilliers, S., \& Niemelä, J. (2014). The concept of ecosystem services in adaptive urban planning and design: A framework for supporting innovation. Landscape and Urban Planning, 125, 254-259. https://doi.org/10.1016/j.landurbplan.2014.01.020.

Albertí, J., Balaguera, A., Brodhag, C., \& Fullana-i-Palmer, P. (2017). Towards life cycle sustainability assessment of cities. A review of background knowledge. Science of The Total Environment, 609, 1049-1063. doi:https://doi.org/10.1016/j.scitotenv.2017.07.179.

Alberti, M. (2008). Advances in urban ecology: Integrating humans and ecological processes in urban ecosystems. Springer.

Alberti, M. (2015). Cities as hybrid ecosystems: Complexity, emergence and resilience in urban ecology. Springer Science \& Business Media.

Amenta, L., \& Attademo, A. (2016). Circular wastescapes. Waste as a resource for periurban landscapes planning. CRIOS, 12, 79-88. https://doi.org/10.3280/CRIOS2016-012008.

Bai, X., \& Schandl, H. (2011). Urban ecology and industrial ecology. In I. Douglas, D. Goode, M. Houcke, \& R. Wang (Eds.), The Routledge handbook of urban ecology (pp. 26-37). Taylor \& Francis e-Library.

Beloin-Saint-Pierre, D., Rugani, B., Lasvaux, S., Mailhac, A., Popovici, E., Sibiude, G., Benetto, E., \& Schiopu, N. (2017). A review of urban metabolism studies to identify key methodological choices for future harmonization and implementation. Journal of Cleaner Production, 163, S223S240. doi:https://doi.org/10.1016/j.jclepro.2016.09.014.

Bidstrup, M., Pizzol, M., \& Schmidt, J. H. (2015). Life Cycle Assessment in spatial planning-A procedure for addressing systemic impacts. Journal of Cleaner Production, 91, 136-144. https:// doi.org/10.1016/j.jclepro.2014.12.027.

Björklund, A. (2012). Life cycle assessment as an analytical tool in strategic environmental assessment. Lessons learned from a case study on municipal energy planning in Sweden. Environmental Impact Assessment Review, 32(1), 82-87. doi:https://doi.org/10.1016/j.eiar.2011.04.001.

Brown, I. T. (2017). Managing cities as urban ecosystems: Fundamentals and a framework for Los Angeles, California. Cities and the Environment, 10(2), 1-30.

Brundtland, G. H. (1987). Our common future. Oxford University Press.

Buhaug, H., \& Urdal, H. (2013). An urbanization bomb? Population growth and social disorder in cities. Global Environmental Change, 23(1), 1-10. https://doi.org/10.1016/j.gloenvcha.2012. 10.016 .

Carta. (2013). Planning in the re-cycle age. In S. Marini \& V. Santangelo (Eds.), Nuovi cicli di vita per architetture e infrastrutture della città e del paesaggio (pp. 59-64). Aracne edtrice.

Chen, S., Chen, B., \& Fath, B. D. (2014). Urban ecosystem modeling and global change: Potential for rational urban management and emissions mitigation. Environmental Pollution, 190, 139-149. https://doi.org/10.1016/j.envpol.2014.03.032.

Ciavatta, S. (2016). Il Riuso Degli Spazi Abbandonati: Il Caso Del 'Mercato Sonato'. Ph.D. thesis, Alma Master Studiorum, University of Bologna.

Collins, J., Kinzig, A., Grimm, N., Fagan, W., Hope, D., Wu, J., \& Borer, E. (2000). A new urban ecology: Modeling human communities as integral parts of ecosystems poses special problems for the development and testing of ecological theory. American Scientist, 88(5), 416-425. Retrieved January 28, 2021, from http://www.jstor.org/stable/27858089.

Conke, L. S., \& Ferreira, T. L. (2015). Urban metabolism: Measuring the city's contribution to sustainable development. Environmental Pollution, 202, 146-152.

Dijst, M. (2013). Space-time integration in a dynamic urbanizing world: Current status and future prospects in geography and GIScience: Space-time integration in geography and GIScience. Annals of the Association of American Geographers, 103(5), 1058-1061. https://doi.org/10.1080/ 00045608.2013.792171.

Dijst, M., Worrell, E., Böcker, L., Brunner, P., Davoudi, S., Geertman, S., Harmsen, R., Helbich, M., Holtslag, A. A. M., Kwan, M.-P., Lenz, B., Lyons, G., Mokhtarian, P. L., Newman, P., Perrels, A., Ribeiro, A. P., Rosales Carreón, J., Thomson, G., Urge-Vorsatz, D., \& Zeyringer, 
M. (2018). Exploring urban metabolism-Towards an interdisciplinary perspective. Resources, Conservation and Recycling, 132, 190-203. doi:https://doi.org/10.1016/j.resconrec.2017.09.014.

Dizdaroglu, D. (2015). Developing micro-level urban ecosystem indicators for sustainability assessment. Environmental Impact Assessment Review, 54, 119-124. https://doi.org/10.1016/j.eiar. 2015.06.004.

Douglas, I. (2012). Peri-urban ecosystems and societies: Transitional zones and contrasting values. In D. McGregor, D. Simon, \& D. Thompson (Eds.), The peri-urban interface: Approaches to sustainable natural and human resource use (pp. 18-29). Earthscan.

Esty, D.C., Levy, M., Srebotnjak, T., \& de Sherbinin, A. (2005). Environmental sustainability index: Benchmarking national environmental Stewardship. Yale Center for Environmental Law \& Policy, Yale University, United States; Center for International Earth Science Information Network, Columbia University, United States.

European Commission. Joint Research Centre. Institute for Environment and Sustainability. (2010). International reference life cycle data system (ILCD) handbook: General guide for life cycle assessment: Detailed guidance. Publications Office. https://data.europa.eu/doi/https://doi.org/10. 2788/38479.

European Environment Agency. (2015). Urban sustainability issues: What is a resource-efficient city?. Publications Office. http://dx.publications.europa.eu/https://doi.org/10.2800/389017.

Gargari, C. (2015). Analisi e valutazione ambientale di un'area al margine del Parco. In M. C. Torricelli (Ed.), ES-LCA e Patrimonio Naturale. Life Cicle Analisi Ambientale e Sociale Di Un'area Protetta (pp. 213-232). Firenze University Press.

Giampietro, M., Mayumi, K., \& Ramos-Martin, J. (2009). Multi-scale integrated analysis of societal and ecosystem metabolism (MuSIASEM): Theoretical concepts and basic rationale. Energy, 34(3), 313-322. https://doi.org/10.1016/j.energy.2008.07.020.

Goldstein, B., Birkved, M., Quitzau, M.-B., \& Hauschild, M. (2013). Quantification of urban metabolism through coupling with the life cycle assessment framework: Concept development and case study. Environmental Research Letters, 8(3), 035024. doi: https://doi.org/10.1088/17489326/8/3/035024.

Grimm, N. B., Grove, J. M., Pickett, S. T. A., \& Redman, C. L. (2008). Integrated approaches to longterm studies of urban ecological systems. In J. M. Marzluff, E. Shulenberger, W. Endlicher, M. Alberti, G. Bradley, C. Ryan, U. Simon, \& C. ZumBrunnen (Eds.), Urban ecology (pp. 123-141). Springer US. doi:https://doi.org/10.1007/978-0-387-73412-5_8.

Haase, D., Larondelle, N., Andersson, E., Artmann, M., Borgström, S., Breuste, J., GomezBaggethun, E., Gren, Å., Hamstead, Z., Hansen, R., Kabisch, N., Kremer, P., Langemeyer, J., Rall, E. L., McPhearson, T., Pauleit, S., Qureshi, S., Schwarz, N., Voigt, A., \& Elmqvist, T. (2014). A quantitative review of urban ecosystem service assessments: Concepts, models, and implementation. Ambio, 43(4), 413-433. https://doi.org/10.1007/s13280-014-0504-0.

Hauschild, M. Z., \& Huijbregts, M. A. J. (2015). Introducing life cycle impact assessment. In M. Z. Hauschild \& M. A. J. Huijbregts (Eds.), Life cycle impact assessment (pp. 1-16). Springer. Doi:https://doi.org/10.1007/978-94-017-9744-3_1.

Hellweg, S., \& Mila i Canals, L. (2014). Emerging approaches, challenges and opportunities in life cycle assessment. Science, 344(6188), 1109-1113. doi:https://doi.org/10.1126/science.1248361.

Hendriks, C., Obernosterer, R., Müller, D., Kytzia, S., Baccini, P., \& Brunner, P. H. (2000). Material flow analysis: A tool to support environmental policy decision making. Case-studies on the city of Vienna and the Swiss lowlands. Local Environment, 5(3), 311-328. doi:https://doi.org/10.1080/ 13549830050134257.

Hobbs, R. J., Arico, S., Aronson, J., Baron, J. S., Bridgewater, P., Cramer, V. A., Epstein, P. R., Ewel, J. J., Klink, C. A., Lugo, A. E., Norton, D., Ojima, D., Richardson, D. M., Sanderson, E. W., Valladares, F., Vilà, M., Zamora, R., \& Zobel, M. (2006). Novel ecosystems: Theoretical and management aspects of the new ecological world order: Novel ecosystems. Global Ecology and Biogeography, 15(1), 1-7. https://doi.org/10.1111/j.1466-822X.2006.00212.x. 
Keirstead, J., Jennings, M., \& Sivakumar, A. (2012). A review of urban energy system models: Approaches, challenges and opportunities. Renewable and Sustainable Energy Reviews, 16(6), 3847-3866. https://doi.org/10.1016/j.rser.2012.02.047.

Kennedy, C., Stewart, I. D., Ibrahim, N., Facchini, A., \& Mele, R. (2014). Developing a multi-layered indicator set for urban metabolism studies in megacities. Ecological Indicators, 47, 7-15. https:// doi.org/10.1016/j.ecolind.2014.07.039.

Kennedy, C. A., Stewart, I., Facchini, A., Cersosimo, I., Mele, R., Chen, B., Uda, M., Kansal, A., Chiu, A., Kim, K., Dubeux, C., Lebre La Rovere, E., Cunha, B., Pincetl, S., Keirstead, J., Barles, S., Pusaka, S., Gunawan, J., Adegbile, M., \& Sahin, A. D. (2015). Energy and material flows of megacities. Proceedings of the National Academy of Sciences, 112(19), 5985-5990. https://doi. org/10.1073/pnas.1504315112.

Kroll, F., Müller, F., Haase, D., \& Fohrer, N. (2012). Rural-urban gradient analysis of ecosystem services supply and demand dynamics. Land Use Policy, 29(3), 521-535. https://doi.org/10.1016/ j.landusepol.2011.07.008.

Lerond, M. (2003). L'évaluation environnementale des politiques, plans et programmes: Objectifs, méthodologies et cas pratiques. Lavoisier.

Li, H., \& Kwan, M.-P. (2018). Advancing analytical methods for urban metabolism studies. Resources, Conservation and Recycling, 132, 239-245. https://doi.org/10.1016/j.resconrec.2017. 07.005 .

Loiseau, E., Junqua, G., Roux, P., \& Bellon-Maurel, V. (2012). Environmental assessment of a territory: An overview of existing tools and methods. Journal of Environmental Management, 112, 213-225. https://doi.org/10.1016/j.jenvman.2012.07.024.

Loiseau, E., Roux, P., Junqua, G., Maurel, P., \& Bellon-Maurel, V. (2013). Adapting the LCA framework to environmental assessment in land planning. The International Journal of Life Cycle Assessment, 18(8), 1533-1548. https://doi.org/10.1007/s11367-013-0588-y.

Loiseau, E., Roux, P., Junqua, G., Maurel, P., \& Bellon-Maurel, V. (2014). Implementation of an adapted LCA framework to environmental assessment of a territory: Important learning points from a French Mediterranean case study. Journal of Cleaner Production, 80, 17-29. https://doi. org/10.1016/j.jclepro.2014.05.059.

Loiseau, E., Aissani, L., Le Féon, S., Laurent, F., Cerceau, J., Sala, S., \& Roux, P. (2018). Territorial life cycle assessment (LCA): What exactly is it about? A proposal towards using a common terminology and a research agenda. Journal of Cleaner Production, 176, 474-485. https://doi. org/10.1016/j.jclepro.2017.12.169.

Magnaghi, R. (2017). Il progetto locale: Verso la conscienza di luogo. Bollati Boringhieri.

Mayer, A. L. (2008). Strengths and weaknesses of common sustainability indices for multidimensional systems. Environment International, 34(2), 277-291. https://doi.org/10.1016/j.envint. 2007.09.004.

Mazzi, A., Toniolo, S., Catto, S., De Lorenzi, V., \& Scipioni, A. (2017). The combination of an environmental management system and life cycle assessment at the territorial level. Environmental Impact Assessment Review, 63, 59-71. https://doi.org/10.1016/j.eiar.2016.11.004.

McDonough, W., \& Braungart, M. (2002). Cradle to cradle: Remaking the way we make things (1st ed). North Point Press.

McPhearson, T., Pickett, S. T. A., Grimm, N. B., Niemelä, J., Alberti, M., Elmqvist, T., Weber, C., Haase, D., Breuste, J., \& Qureshi, S. (2016). Advancing urban ecology toward a science of cities. BioScience, 66(3), 198-212. https://doi.org/10.1093/biosci/biw002.

Minx, J. C., Creutzig, F., Medinger, V., Ziegler, T., Owen, A., \& Baiocchi, G., (2011). Developing a pragmatic approach to assess urban metabolism in Europe. A report to the Environment Agency. Prepared by Technische Universität Berlin and Stockholm Environment Institute, Climatecon Working Paper 01/2011, Technische Universität Berlin.

Mori, K., \& Christodoulou, A. (2012). Review of sustainability indices and indicators: Towards a new city sustainability index (CSI). Environmental Impact Assessment Review, 32(1), 94-106. https://doi.org/10.1016/j.eiar.2011.06.001. 
Mostafavi, N., Farzinmoghadam, M., \& Hoque, S. (2014). A framework for integrated urban metabolism analysis tool (IUMAT). Building and Environment, 82, 702-712. https://doi.org/ 10.1016/j.buildenv.2014.10.020.

Ness, B., Urbel-Piirsalu, E., Anderberg, S., \& Olsson, L. (2007). Categorising tools for sustainability assessment. Ecological Economics, 60(3), 498-508. https://doi.org/10.1016/j.ecolecon. 2006.07.023.

Nitschelm, L., Aubin, J., Corson, M. S., Viaud, V., \& Walter, C. (2016). Spatial differentiation in life cycle assessment LCA applied to an agricultural territory: Current practices and method development. Journal of Cleaner Production, 112, 2472-2484. https://doi.org/10.1016/j.jclepro. 2015.09.138.

Pataki, D. E., Alig, R. J., Fung, A. S., Golubiewski, N. E., Kennedy, C. A., Mcpherson, E. G., Nowak, D. J., Pouyat, R. V., \& Romero Lankao, P. (2006). Urban ecosystems and the North American carbon cycle: Urban ecosystems and the North American carbon cycle. Global Change Biology, 12(11), 2092-2102. https://doi.org/10.1111/j.1365-2486.2006.01242.x.

Qi, W., Deng, X., Chu, X., Zhao, C., \& Zhang, F. (2017). Emergy analysis on urban metabolism by counties in Beijing. Physics and Chemistry of the Earth, Parts A/b/c, 101, 157-165. https://doi. org/10.1016/j.pce.2017.01.024.

Rees, W. E. (2017). Ecological footprints and appropriated carrying capacity: What urban economics leaves out. Urbanisation, 2(1), 66-77. https://doi.org/10.1177/2455747117699722.

Rotmans, J., van Asselt, M., \& Vellinga, P. (2000). An integrated planning tool for sustainable cities. Environmental Impact Assessment Review, 20(3), 265-276. https://doi.org/10.1016/S0195-925 5(00)00039-1.

Russo, M. (2015). Metabolismo urbano per progettare il futuro della città. In M. Carta \& B. Lino (Eds.), Urban Hyper-Metabolism (pp. 75-81). Aracne editrice.

Russo, M. (2017). Riciclo e metabolismo per ripensare il progetto. In C. Gasparrini \& A. Terracciano (Eds.), Dross City. Metabolismo Urbano, Resilienza e Progetto Di Riciclo Dei Drosscape (pp. 3641). List.

Russo, M. (2018). Rethinking resilience, design the city through its metabolism. TECHNE_Journal of Technology for Architecture and Environment, 39-44. doi:https://doi.org/10.13128/TECHNE23200.

Saner, D., Heeren, N., Jäggi, B., Waraich, R. A., \& Hellweg, S. (2013). Housing and mobility demands of individual households and their life cycle assessment. Environmental Science \& Technology, 47(11), 5988-5997. https://doi.org/10.1021/es304084p.

Scarmellini, G. (2015). Prefazione. In M. C. Torricelli (Ed.), ES-LCA e Patrimonio Naturale. Life Cicle Analisi Ambientale e Sociale Di Un'area Protetta (pp. 13-17). Firenze University Press.

Society of Environmental Toxicology and Chemistry. (1993). Guidelines for life-cycle assessment: A 'Code of Practice: from the SETAC Workshop Held at Sesimbra. Sesimbra, Portugal, March 31-April 3, 1993.

Sukopp, H. (2008). On the early history of urban ecology in Europe. In J. M. Marzluff, E. Shulenberger, W. Endlicher, M. Alberti, G. Bradley, C. Ryan, U. Simon, \& C. ZumBrunnen (Eds.), Urban ecology (pp. 79-97). Springer. doi:https://doi.org/10.1007/978-0-387-73412-5_6.

Torricelli, M. C. \& Gargari, C. (2015a). La qualità ambientale di un territorio. Consumo di risorse e impatti. In M. C. Torricelli (Ed.), ES-LCA e Patrimonio Naturale. Life Cicle Analisi Ambientale $e$ Sociale Di Un'area Protetta (pp. 73-115). Firenze University Press.

Torricelli, M. C. \& Gargari, C. (2015b). Sostenibilità ambientale e sociale di un territorio naturale protetto. In M. C. Torricelli (Ed.), ES-LCA e Patrimonio Naturale. Life Cicle Analisi Ambientale e Sociale Di Un'area Protetta (pp. 59-70). Firenze University Press.

Wackernagel, M., \& Rees, W. E. (1997). Perceptual and structural barriers to investing in natural capital: Economics from an ecological footprint perspective. Ecological Economics, 20(1), 3-24. https://doi.org/10.1016/S0921-8009(96)00077-8.

Wegener, M. (2011). From macro to micro-How much micro is too much? Transport Reviews, 31(2), 161-177. https://doi.org/10.1080/01441647.2010.532883. 
Zhang, Y., Yang, Z., \& Li, W. (2006). Analyses of urban ecosystem based on information entropy. Ecological Modelling, 197(1-2), 1-12. https://doi.org/10.1016/j.ecolmodel.2006.02.032.

Zucchetti, S. (2008). Il Marketing Territoriale: Una Leva Per Lo Sviluppo ? Liuc Papers, Serie Economia e Istituzioni, 214, 1-30.

Open Access This chapter is licensed under the terms of the Creative Commons Attribution 4.0 International License (http://creativecommons.org/licenses/by/4.0/), which permits use, sharing, adaptation, distribution and reproduction in any medium or format, as long as you give appropriate credit to the original author(s) and the source, provide a link to the Creative Commons license and indicate if changes were made.

The images or other third party material in this chapter are included in the chapter's Creative Commons license, unless indicated otherwise in a credit line to the material. If material is not included in the chapter's Creative Commons license and your intended use is not permitted by statutory regulation or exceeds the permitted use, you will need to obtain permission directly from the copyright holder. 